\title{
Indo-US Bilateral FDI and Current Account Balance: Developing Causal Relationship
}

\author{
Prof. Dr. Badar Alam Iqbal \\ Adjunct Professor, School of Economics and Finance, \\ Monarch University, Zug, Switzerland \\ Dr. Mohd Nayyer Rahman \\ Assistant Professor, Faculty of Management, \\ Integral University, Lucknow (UP) \\ Prof. Dr. Abdul Turay \\ Interim Chair, School of Business, \\ Kentucky State University, Frankfurt (USA)
}

Doi:10.5901/ajis.2017.v6n1p129

Abstract

Foreign Direct Investment and Current Account Balance are the two important macroeconomic variables considered in overall Balance of Payments (BOP). India and United States have progressed by investing in each other resources and has a significant share in their respective total FDI Inflows. FDI Inflows as per the BPM6 of IMF falls in the Capital Account of Balance of Payments (BOP). The balance of Current Account is related to Capital Account as Capital Account shows the mode of financing. It is through the Capital Account that the deficit of Current Account is financed. FDI is a long term source of financing for the country. The present study aims to develop a causal relationship between Indo-US FDI and Current Account Balance with the help of Granger Causality (Sims, 1980). The Toda and Yamamoto (1995) approach to Causality is followed in the study. The time period for the study is from 2001 to 2014. The study contains seven sections.

Keywords: Indo-US, FDI, Current Account Balance, Granger Causality

\section{Introduction}

India and United States are from two different groups of countries as per UNCTAD. While US is a developed economy, India is considered a developing or emerging economy. It is not surprising in the present world of dependency that there is a strong bilateral economic relationship between India and United States (US). India received FDI Inflows from United States and US also receives FDI Inflows from India. Both countries have a strong economic bonding. However, the quantum of FDI Inflows differs due to the different economic status of both countries. Similarly, the Balance of Payments position of both the countries is different which includes Current Account Balance as well as Capital Account Balance. The difference is both theoretical and empirical. India has not yet divided the Capital Account into Capital and Financial Account while US has followed the division. Apart from this there are also few fundamental differences between the calculations of the two Current Account balances. The reason being that US strictly follows the BPM6 manual of IMF but India has not yet implemented the same. In the present study, attempt is made to develop a causal relationship between Indo-US FDI and their respective Current Account Balances. The study is divided into 7 sections. After introducing to the study in Section 1, Section 2 deals with existing body of literature titled "Review of Literature". Section 3 captures the Conceptual Framework followed by Econometric Models in Section 4. The data is described in Section 5 and the results of the analysis are presented in Section 6 . The study concludes in Section 7. 


\section{Review of Literature}

Relatively less work has been conducted on Indo-US FDI along with Current Account Balance (CAB). Though researchers have attempted to relate FDI and Current Account Balance for the same country but Bilateral FDI has been ignored. One reason may be due to the absence of appropriate theoretical foundations related to Bilateral FDI and components of Balance of Payments. Bilateral Indo-US FDI is basically the Outward FDI from US to India and India's Outward FDI to US. In other words, it is FDI Inflows of India from US and US FDI Inflows from India.

Current Account Imbalances have gradually increased in developed as well as developing countries over the last few decades. The US Current Account Deficit dominates the world and the news of the world (Blanchard, Giavazzi, \& Sa, 2005). Econometric analysis of US FDI shows that market size (Capital) and factor costs (Labour) are important determiners of investment decision. The timing of investment is affected by expectation of short run fluctuations in the dollar as demonstrated by instrumental variable estimation (Barrell \& Pain, 1996). Higgins and Klitgaard (2007) have conducted a study on US Current Account Deficit and why US has been successful in carrying it. They concluded that due to the substantial size of Foreign Investment in United States, US has been able to sustain its Current Account Deficit. Partly this is also due to the rapid financial globalization. However, in case the rate at which US inventory purchase Foreign Assets decreases it may become difficult for US to sustain Current Account Deficit. India altogether plays on a different level. Its dynamics is of a transition economy. There has been quite number of studies on Foreign Direct Investment and Current Account of India's Balance of Payments. Nag \& Mukherjee (2012) identified that FDI Inflows in India has a significant impact on import intensity and thus has a significant impact on Balance of Payments of India. It was found that Current Account and FDI are cointegrated (Siddiqui \& Ahmad, 2007). For India, a unidirectional causality was found from FDI to Current Account and both were found cointegrated in the long run for India (Kaur, Yadav \& Gautam, 2012). According to Hossain (2007), the net effect of FDI is positive on Current Account of Balance of Payments.

\section{Trends in Indo-US Bilateral FDI and Current Account Balance}

Before approaching the econometrics modelling and analysis it is imperative to pay attention to the pattern in the trends of Current Account Balance (CAB) of both economies as well as their respective bilateral FDI. As Current Account Balance is an important component of Balance of Payments it is to be remembered that its value is shown according to the Balance of Payments Manual 6 of International Monetary Fund. All the items that are included in Current Account Balance are uniform for both the economies as both have accepted BPM 6 Manual (though India has taken liberty on few counts). United States being developed economy as per UNCTAD, it has been able to sustain its growth with the help of widening Current Account Deficit. It turns out that CAD can be easily represented as a negative Current Account Balance. In order to make the variables used in the study nominal it is better to use Current Account Balance rather than Current Account Deficit. Though there will be no difference in case CAD is selected to use as a term as in the total sample period for the study the CAB remains negative. Still it is advised to use $C A B$ so that at times of surplus no problem for identification arises. Chart 1 shows the trends in the Indo-US Current Account Balance for the period from 2000 to 2014.

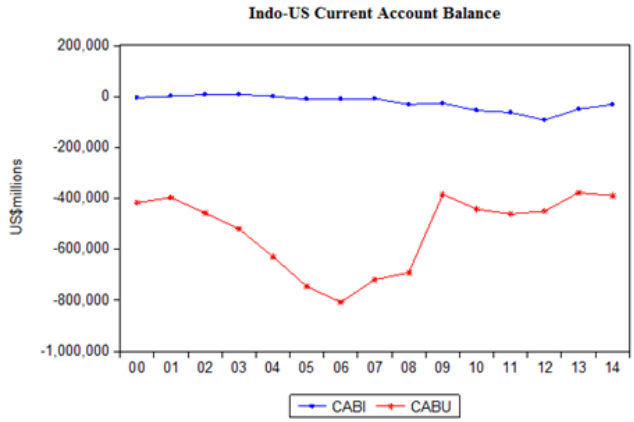

Chart 1:

Source: Prepared by the researcher

In the Chart 1, the variable $\mathrm{CABI}$ denoted Current Account Balance of India and CABU denotes Current Account Balance 
of United States. It is crystal clear that US has much widened negative CAB while India has a very less negative CAB. The mean value of CABI is -24027.67 US\$ millions while for CABU it is -525447.3 US\$ millions. The difference between the mean values can be related to the size and growth of the respective economies. While US is fully industrialized, India has still not reached to that pinnacle. The maximum value for the series CABI is 8772.510 US\$ millions. Surprisingly, India has had a surplus or in other words positive CAB. On the other hand the maximum value of CABU is -376763 US\$ millions which is negative $C A B$ or in simple words a current account deficit. It is just not appropriate to compare the absolute Current Account Balance of US and India when there are quite large differences between the two. A possible and better way can be to see CAB as a percentage of the respective economy's GDP. This will act as a relative measure for both. Chart 2 presents the same.

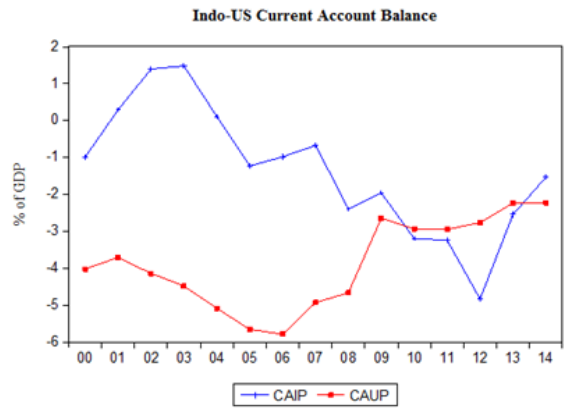

\section{Chart 2:}

Source: Prepared by the researcher

According to the readings of Chart 2, from 2001 to 2005, the value of Current Account Balance of India and US as percentage of their respective GDP has declined. However, after 2005 there has been a recovery for US (while India's percentage still declines). In the last years of the sample period India has recovered a lot on the Current Account Deficit. But the interesting point is that CAB as percentage of GDP has been positive for India in the beginning years but that has not been the case with US for any time during the sample period of the study. Chart 3 presents the trends of the Bilateral Indo-US Foreign Direct Investments.

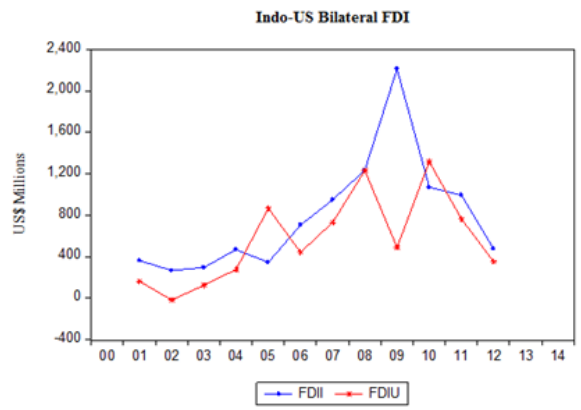

\section{Chart 3:}

Source: Prepared by the researcher

The variables FDII and FDIU in Chart 3 denotes that FDI for India from US and FDI for US from India, respectively. It is clear that from 2001 to 2009, FDI in India from US has increased but after that it has shown a trend of decrease. With respect to FDIU, it shows a mixed trend of rise and fall. From 2001 to 2005 it has increased and then fell for 2006 followed by an increase till 2008. From 2009 it again fell and revived in 2010 to eventually decline in 2012. The mean value of FDII is 782.5858 US\$ millions while for FDIU it is 562.0833 US\$ millions. The mean value shows that United States has invested on an average more in India than India has invested in United States. The maximum value for FDII has been 2212 US\$ millions and for FDIU 1317 US\$ millions. A comparison of the skewness value of FDII and FDIU shows that FDIU is more symmetrical in comparison to FDII. The reason being the value of FDII is 1.39 while that of FDIU is 0.48 that is less farther from the symmetrical measure of 0 . 


\section{Conceptual Framework}

This section expounds the premise developed for developing the causal relationship between Bilateral Indo-US FDI and Current Account Balance. The first relationship is between the FDI in India from US and Current Account Balance of India's Balance of Payments. The second relationship is between the FDI in US from India and Current Account Balance of US Balance of Payments. The theoretical foundations are crystal clear that FDI Inflows are part of Financial Account under Capital Account of Balance of Payments. The theoretical foundations states that a deficit in the Current Account of Balance of Payments is financed through the financial account of Balance of Payments. Thus, FDI Inflows in the short run is a source of finance but its real costs appear in the long run with transfer income to home country.

For developing a causal relationship the concept of causality is integral to the study. Causality stands in opposition to Spurious Correlation. In the words of Raghuram Rajan "Correlation is a superstition while causality is a science". Developing a causal relationship requires exploring the common sense theoretical considerations related to the variables. The variables of the study are described in Annexure I. A little knowledge about Balance of Payments statement supports the notion that FDI Inflows and Current Account Balance are related. FDI Inflows finance the Current Account Deficit. For the term Bilateral FDI, it is argued that it represents the Inflows from the partner country. Thus, FDIU is FDI Inflows from India to US and FDII is FDI Inflows in India from US and both affect the Current Account Balance of respective economies.

\section{Econometric Models and Estimation Methods}

For developing a causal relationship, Granger causality is used but with a non-conventional approach. Toda and Yamamoto (1995) has captured the method to measure causality with data in levels. The only thing required is to find out the order of integration of the two or more series. A simple $X$ Granger cause $Y$ if $Y$ can be better predicted using the histories of both $\mathrm{X}$ and $\mathrm{Y}$ than it can by using the history of $\mathrm{Y}$ alone. In order to test the null hypothesis of $x_{t}$ not Granger causing $y_{t}$ the following unrestricted model specification is used:

Unrestricted: $y_{t}=\alpha+\sum_{i=1}^{P} \alpha_{i} y_{t-i}+\sum_{i=1}^{P} \delta_{i} x_{t-i}+\varepsilon_{t}$

The model used is unrestricted because no condition whatsoever is imposed for lag control on the equations generated for Vector Autoregression Model. For the analysis the equations and hypothesis framed are as follows:

Set 1: FDIU and CABU

$F D I U_{t}=a_{0}+a_{1} F D I U_{t-1}+. .+a_{p} F D I U_{t-p}+b_{1} C A B U_{t-1}+. .+b_{p} C A B U_{t-p}+\mu_{t} \ldots .$.

$C A B U_{t}=c_{0}+c_{1} C A B U_{t-1}+. .+c_{p} C A B U_{t-p}+d_{1} F D I U_{t-1}+. .+d_{p} F D I U_{t-p}+v_{t} \ldots \ldots$.

The hypotheses for equation 1.1 are as follows:

$\mathrm{H}_{01}$ : Current Account Balance of US does not Granger cause FDI Inflows from India in US

$\mathrm{H}_{\mathrm{A1}}$ : Current Account Balance of US Granger cause FDI Inflows from India in US

The hypotheses for equation 1.2 are as follows:

$\mathrm{H}_{02}$ : FDI Inflows from India in US does not Granger cause Current Account Balance of US

$\mathrm{H}_{\mathrm{A} 2}$ : FDI Inflows from India in US Granger cause Current Account Balance of US

In both the cases the rejection of null hypothesis denotes presence of Granger causality with a particular direction.

Set 2: FDII and CABI

$F D I I_{t}=a_{0}+a_{1} F D I I_{t-1}+. .+a_{p} F D I I_{t-p}+b_{1} C A B I_{t-1}+. .+b_{p} C A B I_{t-p}+\mu_{t}$

$C A B I_{t}=c_{0}+c_{1} C A B I_{t-1}+. .+c_{p} C A B I_{t-p}+d_{1} F D I I_{t-1}+. .+d_{p} F D I I_{t-p}+v_{t}$

The hypotheses for equation 1.3 are as follows:

$\mathrm{H}_{03}$ : Current Account Balance of India does not Granger cause FDI Inflows from US in India

$\mathrm{H}_{\mathrm{A} 3}$ : Current Account Balance of India Granger cause FDI Inflows from US in India

The hypotheses for equation 1.4 are as follows:

$\mathrm{H}_{04}$ : FDI Inflows from US in India does not Granger cause Current Account Balance of India

$\mathrm{H}_{\mathrm{A} 4}$ : FDI Inflows from US in India Granger cause Current Account Balance of India

The first step in the procedure is to find out the order of integration of the series FDII, CAB and KAB by using both

Augmented Dicky Fuller unit root test (Dicky \& Fuller, 1981) and Kwiatowski Phillips Schmidt Shin unit root test

(Kwiatowski, Phillips, Schmidt \& Shin, 1992). The various models and hypothesis for ADF test are as follows:

Model A: Check for Stationarity (Neither intercept nor trend)

$\Delta y_{t}=\gamma y_{t-1}+\sum P_{i} \Delta y_{t-i}+\epsilon_{t}$

Model B: Check for Level Stationarity (Only Intercept in the equation) 
$\Delta y_{t}=\mu+\gamma y_{t-1}+\sum P_{i} \Delta y_{t-i}+\epsilon_{t}$

Model C: Check for Trend Stationarity (Intercept and Trend in the equation)

$\Delta y_{t}=\mu+\beta t+\gamma y_{t-1}+\sum P_{i} \Delta y_{t-i}+\epsilon_{t}$

Where in all cases $\mathrm{H}_{0}: \mathrm{Y}=0$ of a unit root time series

$\mathrm{H}_{\mathrm{A}}: \mathrm{Y}<0$ of a stationary time series

As there are differences in asymptotic distribution of the different unit roots, for a cross check, KPSS test would also be used. Remember, that while the null hypothesis of ADF is non stationarity, the null hypothesis of KPSS is stationarity. In KPSS only two models are available:

Model A: Check for Level Stationarity (Only Intercept)

$y_{t}=a_{0}+\varepsilon_{t}$

Model B: Check for Trend Stationarity (Intercept and Trend in the equation)

$y_{t}=a_{0}+\beta t+e_{i}$

Where in all cases $\mathrm{H}_{0}: \sigma_{\mu}^{2}=0$ of a stationary time series

$\mathrm{H}_{\mathrm{A}}: \sigma_{\mu}^{2} \neq 0$ of a unit root/non stationary series

Additionally Phillip Perron Test (1988) and Dicky Fuller- Generalized Least Squares Test will also be used in case both ADF and KPSS fail to conclude the order of Integration.

\section{The Data}

The data for the study is collected from UNCTAD Statistics Database. The data for FDI is taken from the section Bilateral FDI instead of FDI Inflows or Outflows by selecting partner country. The reason is that there were differences in the values and thus it was necessary to use data which is conceptually closer to the objective of the study. In this regard, Bilateral FDI Statistics for India and US was taken. The data for FDI is expressed in US\$ millions. On the other hand, the data for Current Account is taken in absolute as well as expressed in terms of percentage of GDP. The data for Current Account was available from 2001 to 2012. Thus, sample period selected is 2001 to 2014 and values for FDI for 2013 and 2014 are forecasted on the basis of Autoregressive Model. The AR Model for FDII and FDIU is selected with lag 1 to forecast the values for 2013 and 2014 with a dynamic model. The complete dataset is presented in Annexure II.

\section{Results}

\subsection{Causal Relationship between FDIU and CABU}

Going with the Toda and Yamamoto (1995) Approach to causality, it is initially important to identify the order of Integration. This was done with the help of ADF and KPSS and additionally with PP Test. Table 1 and Table 2 presents the output of ADF and KPSS for both FDIU and CABU.

Table 1. Unit Root Tests output for FDIU

\begin{tabular}{|l|c|c|c|}
\hline Test with order & Test statistic & Critical values & Prob. \\
\hline ADF at level & -2.5714 & -3.1199 & 0.1230 \\
\hline ADF at 1 st order differencing & -5.8592 & -3.1449 & $0.0007^{*}$ \\
\hline KPSS at level & 0.2961 & 0.4630 & Nil \\
\hline PP Test at level & -2.5714 & -3.1199 & 0.1230 \\
\hline PP Test at 1 st order differencing & -6.2311 & -3.1449 & $0.0004^{*}$ \\
\hline
\end{tabular}

*indicate significant values and rejection of null hypothesis

Source: Generated by researcher using eviews 9

Table 2. Unit Root Tests output for CABU

\begin{tabular}{|l|c|c|c|}
\hline Test with order & Test statistic & Critical values & Prob. \\
\hline ADF at level & -1.250307 & -3.098896 & 0.6207 \\
\hline ADF at $1^{\text {st }}$ order differencing & -2.942373 & -3.119910 & 0.0673 \\
\hline ADF at $2^{\text {nd }}$ order differencing & -5.727002 & -3.144920 & $0.0008^{*}$ \\
\hline
\end{tabular}




\begin{tabular}{|l|c|c|c|}
\hline KPSS at level & 0.200879 & 0.463000 & Nil \\
\hline PP Test at level & -1.480999 & -3.098896 & 0.5132 \\
\hline PP Test at 1 ${ }^{\text {st }}$ order differencing & -2.939172 & -3.119910 & 0.0677 \\
\hline PP Test at 2nd order differencing & -6.457009 & -3.144920 & $0.0003^{*}$ \\
\hline
\end{tabular}

*indicate significant values and rejection of null hypothesis

Source: Generated by researcher using views

With the help of Table 1 and 2, it is crystal clear that the order of Integration of FDIU is 1 supported by ADF and PP Test and for CABU it is 2 supported by ADF and PP Test output. The maximum order of integration that is $m$ is then equal to 2 . Maximum order of Integration $(\mathrm{m})$ is integral to the Toda and Yamamoto Approach to Causality and thus it cannot be ignored. In the next step, the Vector Auto regression Model with lags 1,1 is estimated but it is found unstable as per AR roots graph and also Lag Order Selection criteria does not accepts maximum lag of VAR to be 1. Thus, a new VAR model with lags 1,2 is estimated and it is found stable. Table 3 shows the VAR lag order criteria for $\operatorname{VAR}(1,2)$.

Table 3. VAR Lag Order Selection Criteria

\begin{tabular}{|c|c|c|c|c|c|c|}
\hline \multicolumn{7}{|c|}{ Endogenous variables: CABU FDIU } \\
\hline \multicolumn{7}{|c|}{ Exogenous variables: $\mathrm{C}$} \\
\hline Lag & LogL & LR & FPE & $\mathrm{AIC}$ & SC & $\mathrm{HQ}$ \\
\hline 0 & -247.2065 & NA & $3.75 \mathrm{e}+15$ & 41.53442 & 41.61524 & 41.50450 \\
\hline 1 & -240.5450 & 9.992219 & $2.45 e+15$ & 41.09084 & 41.33329 & 41.00107 \\
\hline 2 & -232.2508 & $9.676658^{*}$ & $1.31 \mathrm{e}+15^{*}$ & $40.37513^{*}$ & $40.77921^{*}$ & $40.22552^{*}$ \\
\hline \multicolumn{7}{|c|}{${ }^{*}$ indicates lag order selected by the criterion } \\
\hline \multicolumn{7}{|c|}{$\begin{array}{l}\text { LR: sequential modified LR test statistic (each test at } 5 \% \text { level) } \\
\text { FPE: Final prediction error } \\
\text { AIC: Akaike information criterion } \\
\text { SC: Schwarz information criterion } \\
\text { HQ: Hannan-Quinn information criterion }\end{array}$} \\
\hline
\end{tabular}

Source: Generated by researcher using eviews 9

Table 3 clearly highlights that Lag Order Criteria suggests that lag 2 is the appropriate lag for VAR as supported by all the information criteria. Further there is a need to check other stability conditions such as Autocorrelation and AR Roots graph. Both the items are shown in Table 4 and Chart 4.

Table 4. VAR Residual Serial Correlation LM Tests

\begin{tabular}{|c|c|c|}
\hline \multicolumn{3}{|c|}{ Null Hypothesis: no serial correlation at lag order $\mathrm{h}$} \\
\hline Lags & LM-Stat & Prob \\
\hline 1 & 4.200155 & 0.3796 \\
\hline 2 & 5.589576 & 0.2320 \\
\hline 3 & 11.37093 & 0.0227 \\
\hline 4 & 8.356473 & 0.0794 \\
\hline 5 & 2.812985 & 0.5896 \\
\hline 6 & 5.579759 & 0.2328 \\
\hline \multicolumn{2}{|l}{} \\
\hline
\end{tabular}

Source: Generated by researcher using eviews 9 


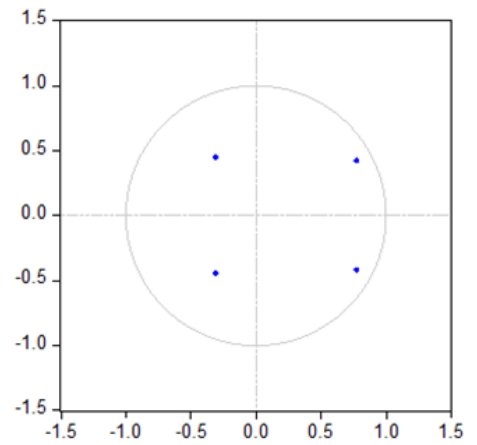

\section{Chart 4:}

Source: Generated by researcher using eviews9

With respect to Table 4, as all the probability values are more than 0.05 except at lag 3 , the null hypothesis of "no serial correlation" cannot be rejected and therefore what is concluded is that overall the model developed is free from autocorrelation. Additionally, the AR roots graphs also show that the model is stable as all the points are within the unit root circle. All four unit points of VAR $(1,2)$ are within the circle and thus the model is stable. Once the model is approved on the basis of the stability conditions, the next step is to re-estimate the model by adding the extra lags as exogenous variables. Remember that as the order of integration of both series was not same there is no need to identify Cointegration between the series. The additional lags for exogenous variables comes out to be 4 (i.e. $p+m=2+2=4$ ) and therefore this adjustment makes sure that data is analyzed while being in levels so that it may not lose its internal dynamics. The outcome of the Granger Causality is shown in Table 5.

Table 5. VAR Granger Causality/Block Exogeneity Wald Tests

\begin{tabular}{|l|c|c|c|}
\hline \multicolumn{2}{|l|}{ Dependent variable: CABU } & \\
\hline Excluded & Chi-sq & df & Prob. \\
\hline FDIU & 1.628420 & 2 & 0.4430 \\
\hline All & 1.628420 & 2 & 0.4430 \\
\hline Dependent variable: FDIU & Chi-sq & df & Prob. \\
\hline Excluded & 1.342933 & 2 & 0.5110 \\
\hline CABU & 1.342933 & 2 & 0.5110 \\
\hline All & & & \\
\hline
\end{tabular}

Source: Generated by researcher using eviews 9

The output shows that both the null hypothesis $\mathrm{H}_{01}$ and $\mathrm{H}_{02}$ are accepted as the probability value more than 0.05 . It means that there is no causality between the two series in the sample period of the study. Further, it indicates that any usage of correlation between the two series for inference will be misleading as there is no statistical causality for the sample period.

\subsection{Causal Relationship between FDII and CABI}

Going with the Toda and Yamamoto (1995) Approach to causality, it is initially important to identify the order of Integration. This was done with the help of ADF and KPSS and additionally with PP Test. Table 6 and Table 7 presents the output of ADF and KPSS for both FDIU and CABU. 
Table 6. Unit Root Tests output for FDII

\begin{tabular}{|l|c|c|c|}
\hline Test with order & Test statistic & Critical values & Prob. \\
\hline ADF at level & -1.8619 & -3.1199 & 0.3376 \\
\hline ADF at 1st order differencing & -4.1553 & -3.1449 & $0.0095^{*}$ \\
\hline KPSS at level & 0.2512 & 0.4630 & Nil \\
\hline PP Test at level & -1.8267 & -3.1199 & 0.3525 \\
\hline PP Test at 1 1st order differencing & -4.1553 & -3.1449 & $0.0095^{*}$ \\
\hline
\end{tabular}

Source: Generated by researcher using eviews 9

*indicate significant values and rejection of null hypothesis

Table 7. Unit Root Tests output for $\mathrm{CABI}$

\begin{tabular}{|l|c|c|c|}
\hline Test with order & Test statistic & Critical values & Prob. \\
\hline ADF at level & -1.219865 & -3.098896 & 0.6341 \\
\hline ADF at 1 st order differencing & -3.407834 & -3.119910 & $0.0307^{*}$ \\
\hline KPSS at level & 0.455342 & 0.463000 & Nil \\
\hline PP Test at level & -1.231931 & -3.098896 & 0.6288 \\
\hline PP Test at 1 st order differencing & -3.407834 & -3.119910 & $0.0307^{*}$ \\
\hline
\end{tabular}

*indicate significant values and rejection of null hypothesis

Source: Generated by researcher using eviews 9

With the help of Table 6 and 7, it is crystal clear that the order of Integration of FDIU is 1 supported by ADF and PP Test and for CABU it is 1 supported by ADF and PP Test output. The maximum order of integration that is $m$ is then equal to 1 . Maximum order of Integration $(\mathrm{m})$ is integral to the Toda and Yamamoto Approach to Causality and thus it cannot be ignored. In the next step, the Vector Auto regression Model with lags 1,1 is estimated and it is found stable. Table 8 shows the VAR lag order criteria for VAR(1,1).

Table 8. VAR Lag Order Selection Criteria

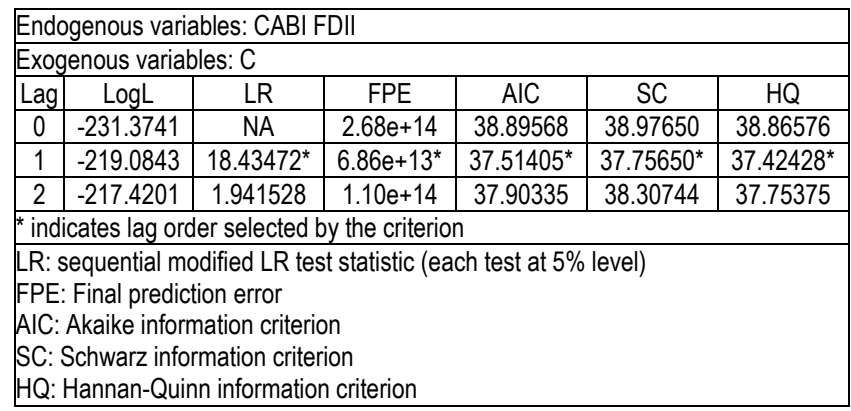

Source: Generated by researcher using eviews 9

Table 8 clearly highlights that Lag Order Criteria suggests that lag 1 is the appropriate lag for VAR as supported by all the information criteria. Further there is a need to check other stability conditions such as Autocorrelation and AR Roots graph. Both the items are shown in Table 9 and Chart 5.

Table 9. VAR Residual Serial Correlation LM Tests

\begin{tabular}{|c|c|c|}
\hline \multicolumn{3}{|c|}{ Null Hypothesis: no serial correlation at lag order $h$} \\
\hline Lags & LM-Stat & Prob \\
\hline 1 & 2.390695 & 0.6643 \\
\hline 2 & 5.313690 & 0.2566 \\
\hline 3 & 6.584625 & 0.1595 \\
\hline 4 & 6.141394 & 0.1888 \\
\hline 5 & 3.458749 & 0.4842 \\
\hline 6 & 4.283714 & 0.3690 \\
\hline
\end{tabular}

Source: Generated by researcher using eviews 9 
Inverse Roots of AR Characteristic Polynomial

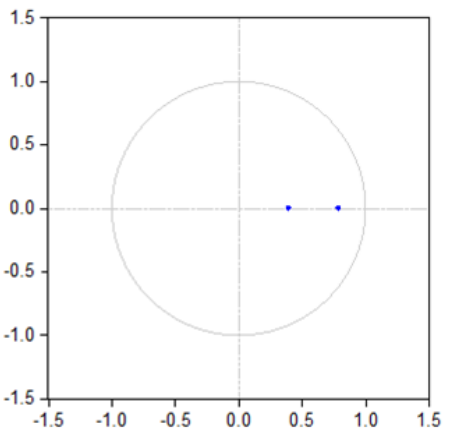

\section{Chart 5:}

Source: Generated by researcher using eviews 9

With respect to Table 9, as all the probability values are more than 0.05 the null hypothesis of "no serial correlation" cannot be rejected and therefore what is concluded is that overall the model developed is free from autocorrelation. Additionally, the AR roots graphs also shows that the model is stable as all the points are within the unit root circle. Both the unit points of VAR $(1,1)$ are within the circle and thus the model is stable. Once the model is approved on the basis of all stability conditions, the next step is to re-estimate the model by adding the extra lags as exogenous variables. The additional lags for exogenous variables comes out to be 2 (i.e. $p+m=1+1=2$ ) and therefore this adjustment makes sure that data is analyzed while being in levels so that it may not lose its internal dynamics. The outcome of the Granger Causality is shown in Table 10.

Table 10. VAR Granger Causality/Block Exogeneity Wald Tests

\begin{tabular}{|l|c|c|c|}
\hline Dependent variable: CABI & \\
\hline Excluded & Chi-sq & df & Prob. \\
\hline FDII & 1.581160 & 1 & 0.2086 \\
\hline All & 1.581160 & 1 & 0.2086 \\
\hline Dependent variable: FDII & & & \\
\hline Excluded & Chi-sq & df & Prob. \\
\hline CABI & 0.778983 & 1 & 0.3775 \\
\hline All & 0.778983 & 1 & 0.3775 \\
\hline
\end{tabular}

Source: Generated by researcher using eviews 9

The output shows that both the null hypothesis $\mathrm{H}_{03}$ and $\mathrm{H}_{04}$ are accepted as the probability value is more than 0.05 . It means that there is no causality between the two series in the sample period of the study. Further, it indicates that any usage of correlation between the two series for inference will be misleading as there is no statistical causality for the sample period.

\section{Conclusion}

The study concludes that the Current Account Deficit of US is much more than India and growth of US economy is financed by the widening Current Account Deficit. The attempt to develop a causal relationship in the sample period has shown that there exists no causality between FDI Inflows of US from India and its Current Account Balance and between FDI Inflows of India from US and its Current Account Balance. The may be due to the small sample period used for the econometric modelling and therefore there is a need to attempt to develop a causal relationship between the same variables over a longer period of time. Thus, in such short run, policy making should consider this result. 


\section{References}

Barrell, Ray.,\& Pain, Nigel. (1996). An Econometric Analysis of US Foreign Direct Investment. The Review of Economics and Statistics, 78(2). 200-207. Retrieved from: http://www.jstor.org/stable/2109921

Blanchard, Olivier.,Giavazzi, Francesco., \& Sa Filipa. (2005). International Investors, the US Current Account, and the Dollar. Brooking Papers on Economic Activity, 1. 1-65. Doi: 10.1353/eca.2005.0010

Dickey, D.A, \& Fuller, W. A. (1981). Likelihood ratio statistics for Autoregressive Time Series with a unit root. Econometrica, 49(4), pp. $1057-1072$.

Higgins, Matthew.,\&Klitgaard, Thomas. (2007). Financial Globalization and the US Current Account Deficit. Current Issues in Economics and Finance, 13 (11).

Hossain, Muhammad. Amir. (2007). Impact of Foreign Direct Investment on Bangladesh's Balance of Payments: Some Policy Implications. Retrieved from: http://www.researchgate.net/publication/254557421_Impact_of_Foreign_Direct_Investment_on_ Bangladesh's_Balance_of_Payments_Some_Policy_Implications

Kaur, Manpreet.,Yadav, Surendra. S., \&Gautam, Vinayshil. (2012). Foreign Direct Investment and Current Account Deficit- A causality analysis in context of India. Journal of International Business and Economy, 13(2), 85-106.

Kwialkowski, D., Phillips, P., Schmidt, P., \& Shin, Y. (1992). Testing the null hypothesis of stationarity against the alternative of a unit root. Journal of Econometrics, 54, 159-178.

Nag, Biswajit.,\& Mukherjee, Jaydeep. (2012). The sustainability of trade deficits in the presence of endogenous structural breaks: Evidence from the Indian economy. Journal of Asian Economics, 23, 519-526. http://dx.doi.org/10.1016/j.asieco.2012.05.003

Phillips, P., \& Perron, P. (1988). Testing for a Unit Root in Time Series Regression. Biometrica, 75, 335-346.

Siddiqui, Danish. Ahmed.,\& Ahmad, Mohsin. Hasnain. (2007). The causal relationship between Foreign Direct Investment and Current Account: An empirical investigation for Pakistan Economy. MPRA Paper No. 19743. Retrieved from http://mpra.ub.unimuenchen.de/19743/

Sims, Ch. (1980). Macroeconomics and Reality. Econometrica, 48, 1-49.

Toda, Hiro. Y., \&Tamamoto, Taku. (1995). Statistical inference in vector autoregressions with possibly integrated processes. Journal of Econometrics, 66, 225-250.

\section{Appendix I}

Variable Descriptions

\begin{tabular}{|c|l|}
\hline FDII & FDI Inflows in India from United States (in US\$ millions) \\
\hline FDIU & FDI Inflows in United States from India (in US\$ millions) \\
\hline CABI & Current Account Balance of India (in US\$ millions) \\
\hline CABU & Current Account Balance of United States (in US\$ millions) \\
\hline CAIP & Current Account Balance of India (as \% of GDP) \\
\hline CAUP & Current Account Balance of United States (as \% of GDP) \\
\hline
\end{tabular}

Note: Notation 1 to any variable means first order differencing of the series while 2 means second order differencing of the series.

\section{Appendix II}

Matrix of Bilateral FDI and Current Account Balance (In US\$ millions; CAIP \& CAUP in \%)

\begin{tabular}{|c|c|c|c|c|c|c|}
\hline Year & CABI & CABU & CAIP & CAUP & FDII & FDIU \\
\hline 2001 & 1410.180 & -396599.0 & 0.291982 & -3.708453 & 364.0000 & 162.0000 \\
\hline 2002 & 7059.500 & -457250.0 & 1.398069 & -4.136737 & 268.0000 & -16.0000 \\
\hline 2003 & 8772.510 & -519090.0 & 1.483516 & -4.478391 & 297.0000 & 125.0000 \\
\hline 2004 & 780.196 & -628524.0 & 0.109048 & -5.085621 & 469.0000 & 277.0000 \\
\hline 2005 & -10283.500 & -745445.0 & -1.227882 & -5.655453 & 346.0000 & 868.0000 \\
\hline 2006 & -9299.060 & -806726.0 & -0.981005 & -5.784884 & 706.0000 & 443.0000 \\
\hline 2007 & -8075.690 & -718641.0 & -0.669565 & -4.931904 & 950.0000 & 731.0000 \\
\hline 2008 & -30972.000 & -690789.0 & -2.393299 & -4.662775 & 1236.0000 & 1231.0000 \\
\hline 2009 & -26186.400 & -384024.0 & -1.956767 & -2.645318 & 2212.0000 & 490.0000 \\
\hline 2010 & -54515.900 & -441963.0 & -3.197798 & -2.933760 & 1070.8100 & 1317.0000 \\
\hline 2011 & -62517.600 & -460358.0 & -3.238419 & -2.947421 & 994.3800 & 764.0000 \\
\hline 2012 & -91471.200 & -449669.0 & -4.833217 & -2.764424 & 477.8399 & 353.0000 \\
\hline 2013 & -49226.000 & -376763.0 & -2.540307 & -2.232908 & 786.5430 & 531.2937 \\
\hline 2014 & -31288.800 & -389525.0 & -1.532950 & -2.222434 & 854.6280 & 583.7919 \\
\hline
\end{tabular}

Source: UNCTAD Statistics 
Appendix III

\section{Summary Statistics}

\begin{tabular}{|l|c|c|c|c|c|c|}
\hline & CABI & CABU & CAIP & CAUP & FDII & FDIU \\
\hline Mean & -25415.27 & -533240.4 & -1.377757 & -3.870749 & 788.0144 & 561.4347 \\
\hline Median & -18234.95 & -458804.0 & -1.380416 & -3.922595 & 746.2715 & 510.6469 \\
\hline Maximum & 8772.510 & -376763.0 & 1.483516 & -2.222434 & 2212.000 & 1317.000 \\
\hline Minimum & -91471.20 & -806726.0 & -4.833217 & -5.784884 & 268.0000 & -16.00000 \\
\hline Std. Dev. & 29920.82 & 152107.5 & 1.819322 & 1.252697 & 516.8726 & 393.3392 \\
\hline Skewness & -0.755361 & -0.596857 & -0.044671 & -0.111489 & 1.461925 & 0.524709 \\
\hline Kurtosis & 2.651373 & 1.787750 & 2.327876 & 1.593861 & 5.086397 & 2.491074 \\
\hline Observations & 14 & 14 & 14 & 14 & 14 & 14 \\
\hline
\end{tabular}

Source: Analysis Output from eviews by researcher

\section{Appendix IV}

Normality Test of Residuals for White Noise

\begin{tabular}{|c|c|c|l|}
\hline Series & Jarque-Bera Stat. & Prob. & Data Decision \\
\hline CABI & 1.402230 & 0.496032 & Normally Distributed \\
\hline CABU & 1.688460 & 0.429888 & Normally Distributed \\
\hline CAIP & 0.268178 & 0.874512 & Normally Distributed \\
\hline CAUP & 1.182386 & 0.553666 & Normally Distributed \\
\hline FDII & 7.526140 & 0.023212 & Not Normally Distributed \\
\hline FDIU & 0.793500 & 0.672502 & Normally Distributed \\
\hline
\end{tabular}

Source: Output from eviews by researcher 